\title{
PROCUREMENT-PRINCIPLE TOWARDS EFFECTIVE MANAGEMENT OF CONSTRUCTION PROJECTS
}

\author{
G.T.N. Veerendra ${ }^{1}$, Ch. Durga Prasad ${ }^{2}$, A.Girish Baburao ${ }^{3}$ \\ ${ }^{I}$ Assistant Professor, Civil Engineering Department, Gudlavalleru Engineering College, Gudlavalleru, Krishna \\ District, Andhra Pradesh, 521356 \\ ${ }^{2}$ Civil Engineering Department, Gudlavalleru Engineering College, Gudlavalleru, Krishna District, Andhra Pradesh, \\ 521356 \\ ${ }^{3}$ Civil Engineering Department, Gudlavalleru Engineering College, Gudlavalleru, Krishna District, Andhra Pradesh, \\ 521356
}

\begin{abstract}
Success factor of a construction project is the value of the facility from an organisation over time. The primary consideration in a successful delivery requires an integrated process in the form of procurement route i.e. to obtain the best value for money. Its necessity is from inception stage itself and the organisation has to choose the right procurement route that suits the client's requirements, experience etc. However, selection will depend on the type of project, but today the demand for construction procurement route is increasing with the trend towards alternative delivery routes such as construction management, design-build and management contracting etc. This fact sheet after analysing different procurement routes enlightens a particular procurement route which has most success ratio (or) special interest for different construction projects justified by qualitative and quantitative approaches.
\end{abstract}

Keywords - Procurement, Environmental Impact Assessment (EIA), Project manager (PM), Multinational Corporation (MNC), Small and medium enterprises (SME's)

\section{INTRODUCTION}

In India, the construction industry is the second largest industry after agriculture. It makes a significant contribution to the national economy and provides employment to large number of people. The use of various new technologies and deployment of project management strategies has made it possible to undertake projects of mega scale by overcoming number of challenges. However, the industry is still facing with some major challenges; dependent on the infrastructure growth story, the Indian EPC market has a plethora of opportunities to offer - an estimated spends of INR17.1 billion. Over the Twelfth Five Year Plan - 50\% of such opportunities are expected to be funded by the private sector. What will differentiate one player from the other is the soundness with which such opportunities are secured and managed. Challenges are inevitable in the current EPC market scenario, but the approach to management of such challenges will be the key to continued success. With global giants entering Indian markets, EPC contractors wanting to ride the wave of double-digit growth will have to constantly improvise and improve their modus operandi to maximize value for their shareholders. (EPC: Driving growth efficiently, 2011)

\section{PROCUREMENT}

The Commission for International Building defines procurement as 'A strategy to satisfy clients' development and/or operational needs with respect to the provision of constructed facilities for a discrete life-cycle'. Hugh Clamp (2007) says 'procurement method' is used to describe the often complex network of relationships which are formed between clients, consultants and construction companies, to enable a building project to be realized. Mastermann (2007) states 'A procurement system is the organisational structure adopted by the client for the implementation and at times eventual operation of a project'. The selected procurement process will have unique benefits to offer the project strategy by identifying risks and financial problems, therefore different projects require different procurement routes, each route will have its own benefits to offer with respect to the standards required and also deals with goals and requirements established for functionality cost, time and quality.

\section{WHAT INFLUENCES THE PROCUREMENT ROUTE CHOSEN?}

There are many factors influencing to choose the procurement route, ranging from the structure of the client organization, to risk management, to market trends. The basic factor is based on the traditional time-cost-quality model. 


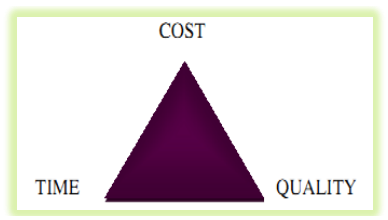

It is generally accepted that only two of the three criteria above can be achieved, and therefore the procurement route should be chosen to maximize the most important criteria.

However, these very broad criteria are often used inappropriately to define project requirements. For this reason there are a series of pre-procurement strategies which should be followed to define, for example, the project requirements prior to choosing the preferred procurement route. These strategies are described in more detail below.

\section{QUANTITATIVE APPROACH}

This dissertation consists of the case studies regarding the construction projects which are following traditional procurement. All the case studies that were considered are government and private projects, where traditional procurement is one main route chosen commonly for every project; Collection of documents related not an easy task. Moreover collecting from government officials is much more difficult. It requires more permission from higher officials in personnel. The table1 shows valuable case studies consolidated data sorted to understand in a simple manner by variables in terms of cost and time analysis. Some conclusions were made after studying all the case studies; it was observed that the minority of the projects have completed earlier, while few of them had exceeded the estimated deadline. Similarly cost for couple of projects was less, whereas other projects were exceeded. The reasons or risks behind may be something; finally client will be affected for cost over-run. Reasons at the back may be importance of the project i.e. its need at the earliest, traffic flow characteristics, political bias, satisfying quality considerations or not, statutory obligations if any, availability of resources, environmental conditions, disputes between the contractors, supply chain, EIA reports, etc.

Table 1: Consolidated data of cost and time analysis of case studies

\begin{tabular}{|c|c|c|c|c|c|c|c|}
\hline \multirow[b]{2}{*}{$\begin{array}{l}\text { S.N } \\
\text { o }\end{array}$} & \multirow[b]{2}{*}{ Project } & \multirow[b]{2}{*}{ Location of Project } & \multicolumn{2}{|l|}{ Cost (INR) } & \multicolumn{3}{|c|}{ Time Duration (Months) } \\
\hline & & & $\begin{array}{l}\text { Estimated } \\
\text { Cost }\end{array}$ & Actual Cost & $\begin{array}{l}\text { Estimate } \\
\text { d Time }\end{array}$ & $\begin{array}{l}\text { Actual } \\
\text { Time }\end{array}$ & $\begin{array}{l}\text { Status of } \\
\text { project }\end{array}$ \\
\hline 1 & $\begin{array}{lr}\text { Construction } & \text { of } \\
\text { High } & \text { Level } \\
\text { Bridge(HLB) } \\
\text { across Bandar } \\
\text { Canal }\end{array}$ & $\begin{array}{l}\text { Tadigadpa village at } 5.2 \\
\text { Kms of Nidmanuru- } \\
\text { Pedapulipaka road in } \\
\text { Krishna District }\end{array}$ & $4,42,87,882$ & $\begin{array}{l}4,60,10,680 . \\
61\end{array}$ & 12 & 9 & $\begin{array}{l}\text { Completed } 3 \\
\text { months early }\end{array}$ \\
\hline 2 & $\begin{array}{l}\text { Construction of } \\
\text { Road Over Bridge } \\
\text { (R.O.B) }\end{array}$ & $\begin{array}{l}\text { At Gunadala at Railway } \\
5.6-7 \mathrm{Km} \text { of Vijayawada } \\
\text { - Gudivada Section in } \\
\text { Krishna District }\end{array}$ & $21,14,32,367$ & $\begin{array}{l}19,60,18,947 \\
.45\end{array}$ & 36 & 40 & $\begin{array}{l}\text { Ongoing late } \\
\text { by } 4 \text { months }\end{array}$ \\
\hline 3 & $\begin{array}{l}\text { Widening \& } \\
\text { Strengthening of a } \\
\text { road }\end{array}$ & $\begin{array}{l}\text { A link road connected } \\
\text { NH.9 toNH.5 through } \\
\text { Indrakeeladri tunnel } \\
\text { from } 0.0 \text { to } 5.44 \mathrm{Km} \text { in } \\
\text { Krishna District } \\
\end{array}$ & $6,57,44,072$ & $\begin{array}{l}5,68,62,047 . \\
87\end{array}$ & 18 & 12 & $\begin{array}{l}\text { Completed } 6 \\
\text { months early }\end{array}$ \\
\hline 4 & $\begin{array}{l}\text { Special repairs to } \\
\text { old Madras- } \\
\text { Calcutta road }\end{array}$ & $\begin{array}{l}\text { From } 1.223 \text { to } 5.6 \mathrm{Km} \text { at } \\
\text { Vijayawada, Krishna } \\
\text { District }\end{array}$ & $1,85,18,520$ & $\begin{array}{l}1,94,25,927 . \\
48\end{array}$ & 12 & 14 & $\begin{array}{l}\text { Completed } 2 \\
\text { months late }\end{array}$ \\
\hline 5 & $\begin{array}{l}\text { Providing water } \\
\text { supply scheme to } \\
26 \text { villages }\end{array}$ & $\begin{array}{l}\text { Koppal } \\
\text { Karnataka }\end{array}$ & $22,44,96,000$ & $\begin{array}{l}21,72,89,678 \\
.40\end{array}$ & 24 & 29 & $\begin{array}{l}\text { Completed } \\
\text { late by } 5 \\
\text { months }\end{array}$ \\
\hline 6 & $\begin{array}{l}\text { Providing water } \\
\text { supply scheme to } \\
83 \text { villages }\end{array}$ & $\begin{array}{l}\text { Koppal } \\
\text { Karnataka }\end{array}$ & $17,15,00,000$ & $\begin{array}{l}17,88,74,504 \\
.00\end{array}$ & 36 & 32 & $\begin{array}{l}\text { Ongoing can } \\
\text { be completed } \\
4 \quad \text { months } \\
\text { early }\end{array}$ \\
\hline 7 & $\begin{array}{lr}\text { Rajiv } & \text { Gandhi } \\
\text { National } & \text { Drinking } \\
\text { Water Technology } \\
\text { Mission } \quad \text { Sector } \\
1 \& 2 \text { of Cluster 2 }\end{array}$ & $\begin{array}{l}\text { Koppal } \\
\text { Karnataka }\end{array}$ & $19,80,00,000$ & $\begin{array}{l}19,33,86,600 \\
.00\end{array}$ & 18 & 16 & $\begin{array}{l}\text { Completed } 2 \\
\text { months early }\end{array}$ \\
\hline
\end{tabular}


The case studies that have been considered are from different areas of civil engineering. Here it can be observed that the first two case studies relate to newly construction projects whereas next two replicate the maintenance and repair works and the last three are regarding the construction for provision of water supply to different villages. Following are the graphs which depict comparison of cost and duration analysis for each type of construction. These graphs can show the deviation in cost and also in time for different projects.
Based on the data the deviation can be seen and author can acquire some inferences for what kind of project is traditional procurement actually suitable. The behaviour of traditional procurement in different stages of construction i.e. preconstruction (design stage), construction stage and postconstruction stage (Handing over the work with required specifications and approval of work done) can also be studied.

\subsection{Newly Construction Projects:}

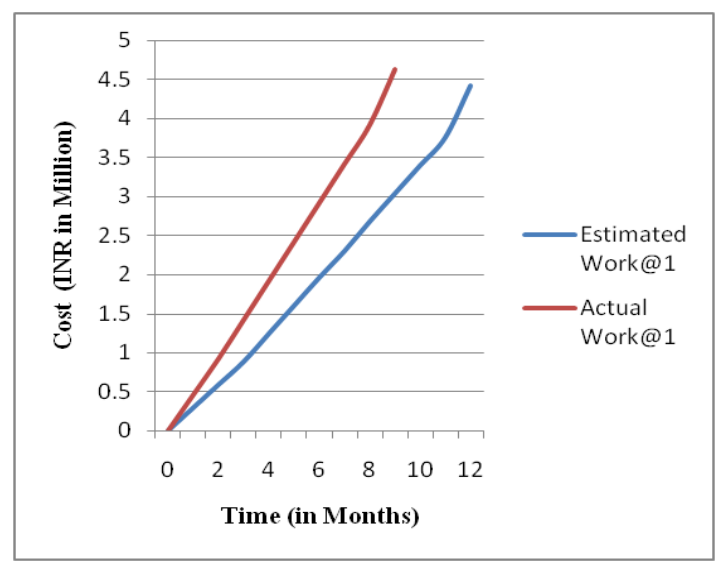

Fig. 2(a) Case Study 1

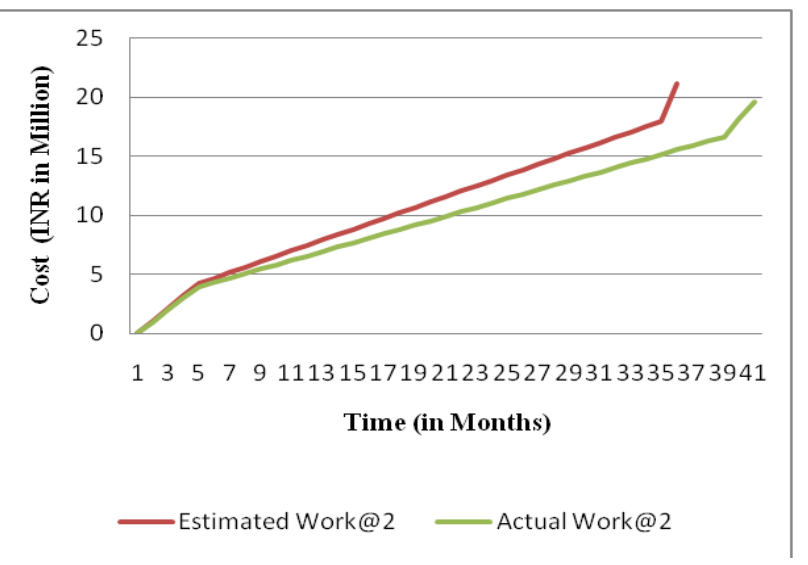

Fig. 2(b) Case Study 2

So based on the above graphs we can infer that the traditional procurement is much suitable for the projects which are small whereas there can be a slight delay when huge projects are undertaken. In most of the projects it was found that the projects are delayed mostly during the construction stage. Thus procurement has to play a vital role when construction is going on. Usually with delay in project may increase its cost. But here the cost is less compared to the estimated. This implicates it is purely due to lack of man power the construction stage might have been affected or else long run projects must have completed earlier. In order to support authors views a questionnaire survey has been done.

\section{QUALITATIVE APPROACH}

To understand the rationale behind the cost over runs and the early finish or delay for the case studies, a qualitative approach was performed in the form of questionnaire survey.. Out of 100 questionnaires distributed to the professionals from various Indian government engineering departments of the projects on which case studies were done, participants are as fallows-Executive Engineers (EE), Deputy Executive Engineers (DEE) and Assistant executive engineers (AEE). Out of which seventy eight (68) valid responses were received representing a response rate of $68 \%$. This may be seen as a satisfactory response rate.

To understand the use of procurement by the respondents it was observed that $87 \%$ of the respondents replied by stating that they use procurement routes in their undertaken projects whereas $10 \%$ people said they are not currently implementing its use within and $3 \%$ people were planning 
to implement in future. No respondent replied that they were not interested to use the procurement route. This shows that procurement route is much needed in any construction project for its smooth functioning and governance.

\subsection{Technical Issues}

With respect to the procurement routes, the respondents were asked to point out the problems that are usually faced at what stage of construction is shown in the fig $5,45 \%$ responded as construction stage, $16 \%$ during lending the payments, $13 \%$ each during delivery stage, $18 \%$ during design process and just 5\% during pre-construction whereas $3 \%$ during inception.

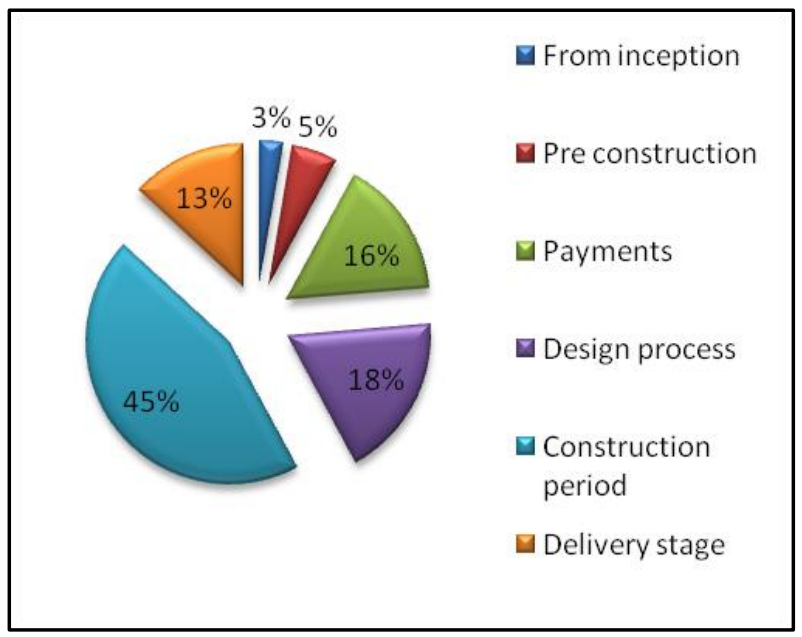

Fig. 5 Problems faced at various stages of construction

Fig 6 illustrates about - which type of procurement route will they choose for every project that was tackled by the individual, $50 \%$ had highly recommended with project management procurement route and $16 \%$ for Design and Build procurement route. $8 \%$ suggested for depending upon the client's experience; yet surprisingly only $21 \%$ supported Traditional procurement and hardly $5 \%$ of people backing up the Public Private Partnership kind of procurement.



Fig. 6 Type of Procurement route suggested by the respondents
Reply of the respondents for simulation between mechanical and electrical engineers affecting the procurement route. Very typical response from fig 7 shows that $12 \%$ of them are not able to link this question to the procurement route $47 \%$ of them says yes they agree to some extent.

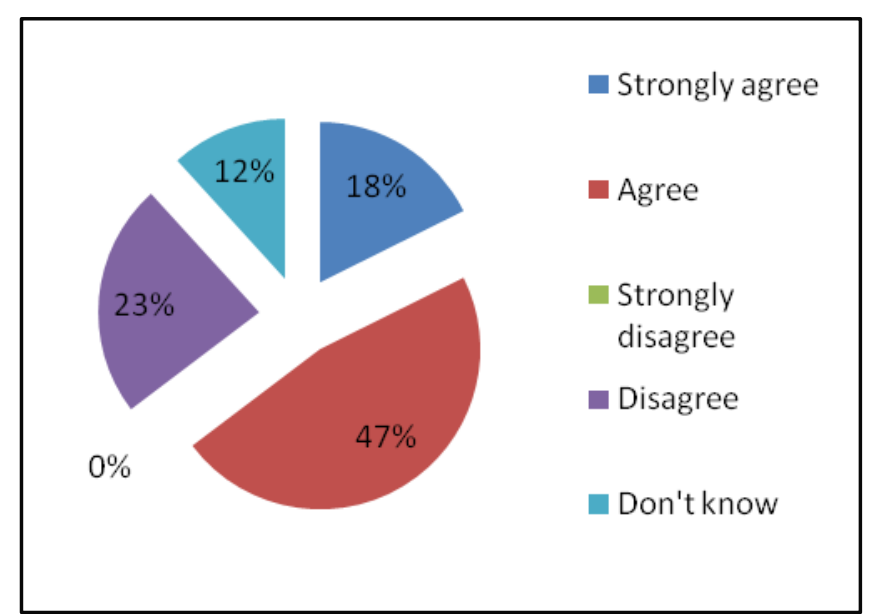

Fig. 7 Time consumption for Simulation between M\&E, Main and sub-contractors in design and planning process

Thus the author infers that every stage will have its own importance but during the construction stage it is more important that designs should satisfy the executor's performance and requirements of the end user. Payments also play a key role as there are labourers who work as daily wage workers and few on monthly salary basis; without paying them on time they can't show interest towards work or else they can even go on strike purely affecting the delay in the planned work and thereby affecting the procurement route. If the delivery is not as per the client's requirements then the work should be done again which creates a lot of depletion of time. As the work in the pre-construction period and that in the inception is done using management softwares like MSP, primavera and schedules by PM's experience will help him to handle every tough situation but the situation can't be guessed at the earliest hence it does not play a vital role in creating problems using procurement route. Moreover inferring that the project management procurement is being highly preferred it is due to MNC companies will have their own design engineers, contractors, consultants etc can be entirely guided by them, so that advantage will create a greater difference towards whole life cycle of the project. Hence in such a case author supports the Design and Build and also project management procurement route. But what is the case for SME's, author supports that the traditional procurement route gives the optimum results and which is best suited for no-experienced on construction. Furthermore in the discussion regarding the simulation of mechanical and electrical engineers to the procurement route; author infers that yes it has to play a key role because without their inclusion the schedule for planning increases the duration of work and thereby affecting the job duration cumulatively. The reason may be that communication is essential to aid with data, Knowledge transfer and data sharing from the different departments is very important. 
It is traced in fig 8, that $53 \%$ expressed that they were strongly agreeing and $34 \%$ agreed that the selection of procurement route will affect the success or failure of the project. This shows that still there is a lack of knowledge in the procurement route and methodologies.

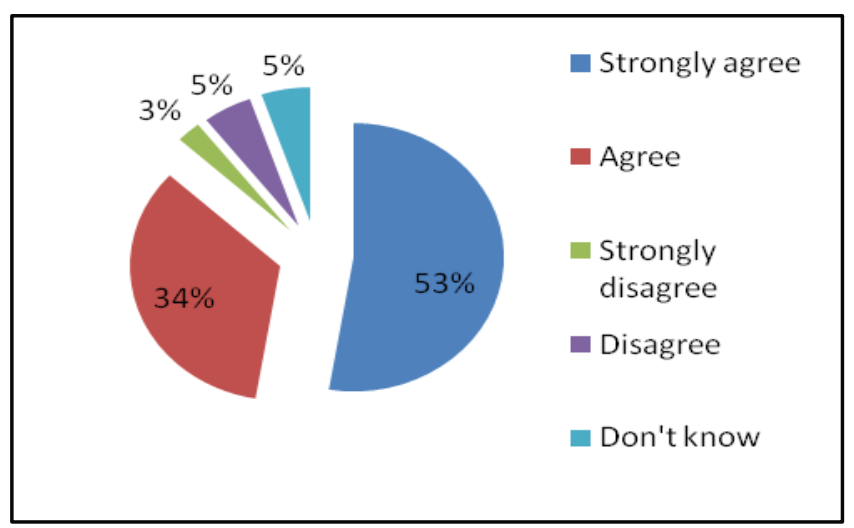

Fig. 8 Success/Failure of a project depending upon selection of procurement route

Respondents are asked to answer, how much emphasis they are giving to the project in terms of time, budget, required quality, value of money, management and political bias, fig 9 will illustrate the results.

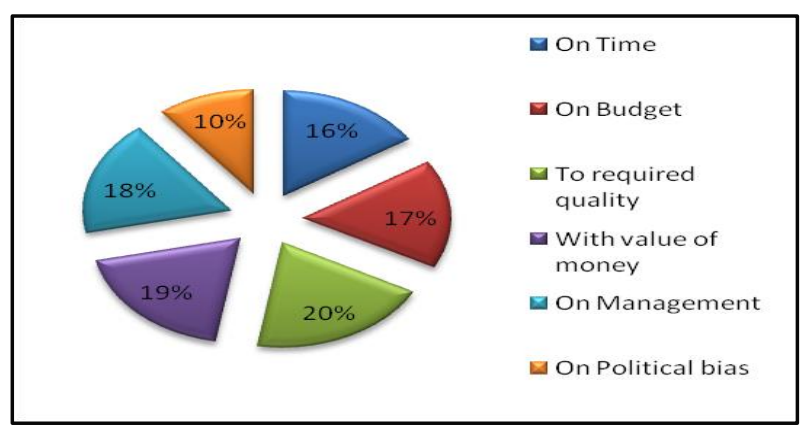

Fig. 9 Proportion of the project completion

The results show that respondent's perception on considering the importance of procurement route in the industry and have an important role to play within all members of the project team.

\subsection{Discussions}

The results of the data analysis are presented to address the research objectives, and challenges faced by the individuals when using procurement during the each stage, this paper was chosen to find some of the problems faced by the professionals in the current construction industry. Traced that some of the respondents were not familiar with procurement where others were, but did not utilize it and need to develop their skills in order to do so. At the same time procurement is an important method in the industry and requires lots of research.

\subsection{Limitations}

It is acknowledged that the research study has some limitations. To additional this questionnaire survey process the use of more case studies and interviews would have been beneficial. Interviews in particular can trace many issues and obtain more information from the respondents.

Furthermore, the questionnaire survey itself may also have some limitations due to its coverage and response received. It was initially estimated that the response rate would be higher but that proved satisfactory results. Lack of time for stakeholders and us to complete our research upon the data collection approach and survey regrets the data else it would have given more appropriate results.

\subsection{Recommendation for Further Research}

The issue of alternate procurement selection needs to be observed and by applying other research tools to provide the appropriate procurement route that can fit for construction environment. It is recommended that such a study should cover wider range of respondents including players from different construction companies from different cities, public sector clients and construction professionals with rich experience on procurement issues. Furthermore, this research could be developed to explore more ideals on the other procurement strategies that can improve the performance in construction industry and assist in its quest for achieving value of money, sustainable projects and saving environment.

\section{CONCLUSIONS}

After the entire paper exclaims that no procurement route gives the best of the results. Each of has its own flaws and advantages. Whereas it would have been better if traditional procurement was used all over to maximum possible extent. But due to the development in technology and organization level it has been almost alleviated and just existing to some extent in some small scale construction projects and won't work for international projects and super fast projects. The basic advantage behind that was found that this is the only procurement route (traditional) that has the least risk; whereas it may take more time to complete the project. Here it was also observed that the quality aspect was also good and satisfactory for the clients. On the other hand Project management procurement though was supported by the most of the respondents; it can be used only if the huge project has to be completed within a short span of time along with no extent for capital consideration. But as the base of any procurement route is traditional it can render to development of a new procurement route which can subject to futuristic recommendation. Moreover the survey and case studies that were collected showed that projects are made up to the quality as prime importance along with value of money then conforming to time and budget, political bias are considered as of least importance in successful completion of a project. It is recommended that traditional procurement is much suited for small scale industry related projects; furthermore it is fully merged in to industry but still needs more research and dedication from industry players. Value for money is much important for the projects, if client/ project manager/ key stake holders are having good experience on projects with project management procurement; it is recommended 
that traditional procurement is much suited for any kind of projects.

\section{ACKNOWLEDGMENTS}

We would lay our sincere gratitude towards all the employees of R\&B Circle, Vijayawada and Sri Srinivasa Construction(I) Pvt.Ltd., Karnataka for providing us with necessary case studies. Our special thanks to the participants from various localities and individuals who made information available for our research and assisted by completing the questionnaire for this dissertation.

\section{REFERENCES}

[1] Challenges before construction industry in India, Arghadeep, LaskarandC.V.R.Murthy, Dept. of civil engineering, Indian Institute of Technology, Kanpur 2004.

[2] Chartered Institute of Building (2002), Code of Practice for Project Management for Construction and Development, 3rd ed. Oxford: Blackwell Publishing. P11-26.

[3] CIOB (chartered Institute Of Building), a report exploring procurement in the construction industry.

[4] Cox, A. \& Townsend, M. (1998), Strategic Procurement in Construction. 2nd Ed. Great Britain: Redwood Books, pp25- 150

[5] Davies, M.B. (2007). Doing a Successful Research Project using qualitative or quantitative methods, London: Palgrave Macmillan.p311.

[6] Department of Business and Innovative skills. (2011). HM Government. Strategy for Sustainable Construction Progress Report. 1 (1), 15-60

[7] Dorsey, R.W (2004). Project Delivery Systems for Building Construction. 2nd ed. San Diego, CA: Associated General Contractors of America. Pp1530.

[8] ERNST \& YOUNG, Engineering, and Procurement\& Construction (EPC): Driving growth efficiency.

[9] Hibberd,Z (1991). Procurement effects on co-optation in client, Oxford: Black well science limited. p240-54

[10] Laedre Ola (Norway), $19^{\text {th }}$ IPMA World Congress, New Delhi, India, (13-16 November 2005), Procurement route in 3 Norwegian Building \& construction projects.

[11] Luis F. Alarcón, Rodrigo Rivas, and Alfredo Serpell .Evaluation and improvement of the procurement process in construction projects.

[12] Masterman, J.W.E (2002). An introduction to building procurement systems. 2nd ed. London: Spon press. P.17-21.

[13] Masterman, JE 2002, An Introduction to Building Procurement Systems, Spon Press, eBook Collection (EBSCOhost), EBSCOhost, viewed 30 July 2012.

[14] Miss. Joanne Larmour (June-2011), A study of procurement route $\&$ their use in the commercial sector., Thesis

[15] Per Erik Eriksson, Mats Westerberg, Effects of procurement on construction project performance.
[16] Prince .O. (2007). Validating a model of cooperative procurement in the construction industry. International Journal of Project management. 27 (2), 552-559.

[17] Project Management Institute Inc., (2008). A Guide to the Project Management Body of Knowledge. 4th edition.

[18] QUT Science \& Engineering Centre ., Construction Procurement Basics - Traditional procurement methodologies with a non-traditional Case Study

[19] SandeepVerma .Electronic Government Procurement in India: A framework analysis of access to knowledge and access to opportunity. India: H. C. M. Rajasthan State Institute of Public Administration Jaipur, Rajasthan. Paper\#10.

[20] Shenhar, A.J. and Dvir, D. (2007). Project management research - the challenge and opportunity. Project Management Journal. 38 (2), pp 93-9.

[21] Taraka. N. VeerendraGanugula , (october2012), The challenges faced by the Project Manager when using BIM (Building Information Modelling) during the Design Stage of a Project Management Procurement route,

[22] The Royal Institute of chartered surveyors/Davis Langdon (2007) "Contracts in use: a survey of building contracts in use during 2007".

[23] Walker, D.H.T. and Rowlinson, S (2008). Procurement Systems. New York: Taylor \& Francis. Pp1-18. 